\title{
Accounting and Engineering Students' Perceptions of Good Teaching in Universities
}

\author{
Dr. Terri Trireksani \\ Murdoch Business School \\ Murdoch University
}

Received: July 12, 2012 Accepted: August 21, $2012 \quad$ Published: December 1, 2012

doi:10.5296/ajfa.v4i2.2096 URL: http://dx.doi.org/10.5296/ajfa.v4i2.2096

\begin{abstract}
The purpose of this study is to investigate accounting and engineering undergraduate students' perceptions of good teaching and consider whether indicators of good teaching are common irrespective of the area of study. A good teaching questionnaire was implemented to collect the data which were used to examine perceptions of accounting students about good teaching and compare them with those of engineering students. The findings suggest that both accounting and engineering undergraduate students agree that the design of the course, the lecturers' comments on their work, and feedback from the lecturers on their progress are the most important indicators of good teaching. Overall, the students have similar perceptions regarding the importance of indicators of good teaching irrespective of their gender or year of study.
\end{abstract}

Keywords: Accounting, Engineering, Students, Good Teaching, Universities 


\section{Introduction}

The use of student ratings utilising student perceptions of lecturers' performance in university teaching has been commonly used as a major component in teaching evaluation and as an essential source of information in performance management in general, including in promotion decisions. There have been some comments and criticisms regarding the instruments that were used to collect the data from the students, whether they could capture the lecturers' ability to promote learning or whether the indicators in the instruments have captured the aspects of good teaching that the students want (e.g. Blackmore, 2009; Emery, Kramer and Tian, 2003; Vieira, 2002). Hence, the main question is "What is good teaching?" Surely there would not be a clearly definitive answer to this question, although we could define some generally accepted indicators of good teaching based on various studies in the existing literature in this area. Prior studies have also suggested that student perceptions of good teaching may be influenced by various factors, such as among others, area of study, cultural values, gender, age and level of education (e.g. Botas, 2008; Feldman, 1976; Fuhrman, Fuhrman and De Lay, 2010; Goodwin and Stevens, 1993; Hativa, 1984; Holmes and Papageorgiou, 2009; Kember, Jenkins and Ng, 2003, 2004; Mitsis and Foley, 2009; Tootoonchi, Lyons and Hagen, 2002; Xiao and Dyson, 1999).

This study is interested in obtaining the views of undergraduate students on what they perceive to be good indicators of good teaching. There have been some studies that investigate this issue in general, but there has been a lack of studies that investigate whether there are perceptive differences between students who study in different area. In this study, the main interest is the perceptions of good teaching from accounting and engineering undergraduate students. Hence, the main purposes of this study are to investigate which attributes of good teaching are considered important by accounting and engineering undergraduate students, and to examine whether there are any differences between the perceptions of accounting students and those of engineering students. The study also investigates whether there are any differences between the perceptions of undergraduate students based on their gender and year of study.

\section{Student perceptions of good teaching}

Feldman's (1976) paper which examined more than 70 studies that evaluated students' perceptions of good teaching suggested that engineering undergraduate students perceived a few lecturers' attributes, such as clear speech and explanation, well prepared lectures, and enthusiastic approach as good indicators of good teaching. Prior studies involving business related students have suggested a few good indicators of good teaching as perceived by the students, such as communication skills, knowledge of the subject matter, overall attitude, fairness and feedback (e.g. Holmes and Papageorgiou, 2009; Tootoonchi et al., 2002). These findings are in agreement with Xiao and Dyson's (1999) study on the perceptions of undergraduate accounting students which suggested a few good indicators of good accounting teaching, such as being knowledgeable, effective teaching approaches, being responsible and conscientious, making teaching interesting, and ability to encourage and facilitate independent thinking. 


\section{Ml Macrothink}

Asian Journal of Finance \& Accounting

ISSN 1946-052X

2012, Vol. 4, No. 2

Considering that it is difficult to indicate the differences between the perspectives of accounting and engineering undergraduate students regarding good teaching from the current literature, this study develops a tentative proposition, namely:

P1 Accounting undergraduate students will have relatively similar scores in the good teaching scales compared with engineering undergraduate students.

Existing literature in this area has not provided a clear suggestion or conclusive empirical findings on whether perceptions of good teaching are different between female and male undergraduate students. One notable study by Mitsis and Foley (2009) examining the perceptions of culturally diverse business students suggested that gender was not a variable that could explain variation in students' perceptions of good teaching. Accordingly, this study adopts this suggestion from Mitsis and Foley (2009), and develops a tentative proposition, namely:

P2 Female undergraduate students will have relatively similar scores in the good teaching scales compared with their male counterparts.

Some prior studies in perceptions of good teaching have examined the perceptions of undergraduate, master and doctoral students (e.g. Botas, 2008; Crumbley, Henry and Kratchman, 2001; Fuhrman et al., 2010; Tootoonchi et al., 2002; Xiao and Dyson, 1999). However, there has been a lack of studies that examine the differences of perceptions among undergraduate students about good teaching at different levels of study. Considering that there are no prior studies that could provide some in indications on this is sue, this study tries to investigate this subject by testing the following proposition:

P3 Undergraduate students will have relatively similar scores in the good teaching scales irrespective of their year of study.

\section{Research method}

\subsection{The survey instrument}

This study utilises the Good Teaching Scales (GTS) developed by Graduate Careers Australia (see www.graduatecareers.com.au). GTS focuses on the nature of teaching experienced during a course and uses six items to measure student perceptions of teaching. The items cover issues such as comments, feedback, motivation, ability to explain, efforts, and empathy (see Table 1). The questionnaire in this study was designed as an anonymous questionnaire and adopted these six GTS items with one additional question about the ability to design the course. The questionnaire asked the respondents' perceptions about the level of importance of each of these seven items using a five-point scale. The five points represented the following: 1 = unimportant; 2 = of little importance; 3 = moderately important; 4 = important; 5 = very important. Subsequently, several questions were added to the questionnaire to collect data on the respondents' area of study, gender, and year of study (i.e. first, second or third year of study). 
Table 1. Good Teaching Scales

\begin{tabular}{|c|l|}
\hline Label & \multicolumn{1}{c|}{ Item } \\
\hline GTS01 & The teaching staff put a lot of time into commenting on my work.. \\
\hline GTS03 & The teaching staff normally gave me helpful feedback on how I was going. \\
\hline GTS10 & The teaching staff of this course motivated me to do my best work. \\
\hline GTS15 & My lecturers were extremely good at explaining things. \\
\hline GTS16 & The teaching staff worked hard to make their subjects interesting. \\
\hline GTS27 & $\begin{array}{l}\text { The teaching staff made a real effort to understand difficulties I might be having with } \\
\text { my work. }\end{array}$ \\
\hline
\end{tabular}

Source: Graduate Careers Australia (2011)

\subsection{Participants}

Indonesian National Education Systems allow higher education institutions to be run in the forms of universities, institutes, colleges, academies, and polytechnics. The latest figures show that there are nearly 3,000 higher education institutions in Indonesia including 82 public higher education institutions (see www.dikti.go.id). The participants in this study were accounting and engineering undergraduate students attending universities in two big cities in Indonesia. The engineering students included in this study were those majoring in civil engineering, industrial engineering, and chemical engineering. There were some responses from students majoring in other engineering related areas, but the numbers were not significant and hence excluded from the final data.

Data were collected only from respondents who were happy to voluntarily participate in the survey. The data collection process started by randomly approaching university students at a few public places where they usually hang out (such as shopping malls and food courts) and asked them whether they were accounting or engineering students, and whether they were interested in participating in an anonymous survey and answered ten simple questions regarding good teaching. To avoid any inconvenience, the request to each student was only made once. A thank you was immediately given to students who rejected the request, and no second request was made. Those who voluntarily agreed to participate were asked to complete a simple anonymous (Indonesian translated) questionnaire with ten questions (as described previously). The process worked well and responses were recorded quickly and easily. Five hundred and eighty three responses were received, and five hundred and twenty eight responses were usable. Two hundred and eighty respondents were female, and two hundred and fourty eight respondents were male. Three hundred and twenty three respondents were accounting students, and two hundred and five respondents were engineering students.

\subsection{Descriptive statistics}

Descriptive statistics for the seven-item scales are presented in Table 2. 


\section{Macrothink}

Table 2. Good teaching descriptive statistics $(n=528)$

\begin{tabular}{|c|c|c|c|c|c|c|c|}
\hline & \multicolumn{7}{|c|}{ Good Teaching Indicators } \\
\hline & $\begin{array}{c}\text { Comment } \\
\text { on } \\
\text { students' } \\
\text { work }\end{array}$ & $\begin{array}{c}\text { Give } \\
\text { helpful } \\
\text { feedback } \\
\text { on how } \\
\text { students } \\
\text { are going }\end{array}$ & $\begin{array}{c}\text { Motivate } \\
\text { students } \\
\text { to do their } \\
\text { best work }\end{array}$ & $\begin{array}{c}\text { Explain } \\
\text { things } \\
\text { very } \\
\text { well }\end{array}$ & $\begin{array}{c}\text { Work hard } \\
\text { to make } \\
\text { their } \\
\text { subjects } \\
\text { interesting }\end{array}$ & $\begin{array}{c}\text { Make a real } \\
\text { effort to } \\
\text { understand } \\
\text { difficulties } \\
\text { students might } \\
\text { be having with } \\
\text { their work }\end{array}$ & $\begin{array}{c}\text { Design } \\
\text { the } \\
\text { course } \\
\text { very } \\
\text { well }\end{array}$ \\
\hline Mean & 4.05 & 4.07 & 3.48 & 3.85 & 3.70 & 3.35 & 4.05 \\
\hline Std & 0.84 & 1.00 & 1.25 & 0.97 & 1.04 & 1.31 & 0.90 \\
\hline dev & 3 & 1 & 1 & 2 & 1 & 1 & 1 \\
\hline Minimum & 3 & 5 & 5 & 5 & 5 & 5 & 5 \\
\hline
\end{tabular}

\section{Analyses and findings}

\subsection{Overall student perceptions of the level of importance of good teaching indicators}

It can be seen from the descriptive analysis (Table 2) that undergraduate students perceived all seven of the good teaching indicators as important. There were three indicators that received very high mean scores: "Comment on students' work", "Give helpful feedback on how students are going", and "Design the course very well", with mean scores of 4.05 (out of 5), 4.07 (out of 5), and 4.05 (out of 5) respectively. Two of the indicators received quite high mean scores: "Explain things very well" and "Work hard to make their subjects interesting", with mean scores of 3.85 (out of 5) and 3.70 (out of 5) respectively. The remaining two indicators received moderate mean scores: "Motivate students to do their best work" and "Make a real effort to understand difficulties students might be having with their work", with mean scores of 3.48 (out of 5) and 3.35 (out of 5) respectively. These overall results indicate some consistencies with the findings by Feldman (1976), Holmes and Papageorgiou (2009), Tootoonchi et al. (2002), and Xiao and Dyson's (1999).

\subsection{Students' perceptions of good teaching by area of study}

The means of the scores on good teaching scales of accounting undergraduate students as compared to those of engineering undergraduate students are shown in Table 3.

The initial indications from the descriptive statistics showed that there were three indicators that received similar scores from both the accounting and the engineering undergraduate students: "Comment on students' work", "Give helpful feedback on how students are going", and "Design the course very well". The results of the comparison of the mean scores for these 
three indicators confirmed that there were no significant differences between the scores given by the accounting undergraduate students and those given by the engineering undergraduate students. These indicate that both accounting and engineering undergraduate students have similar perceptions regarding the importance of these three indicators of good teaching. The mean scores also show that these three indicators received the highest scores among the seven good teaching indicators, with scores from accounting and engineering undergraduate students of 4.02 and 4.09, 4.08 and 4.05, and 4.01 and 4.11, respectively for "Comment on students' work", Give helpful feedback on how students are going", and "Design the course very well' indicators.

The analysis of the descriptive data showed an initial indication that the scores from the accounting and the engineering undergraduate students for the remaining four good teaching indicators were quite different. The results of the comparison of the mean scores for these four indicators confirmed that the scores given by the accounting undergraduate students were significantly different than those given by the engineering undergraduate students, in which the level of importance of these indicators perceived by accounting undergraduate students were comparatively higher to those perceived by the engineering undergraduate students.

The comparison of mean scores for the "Explain things very well" indicator showed a slight difference, with a score of 3.99 from the accounting undergraduate students and a score of 3.62 from the engineering undergraduate students. The comparison of mean scores for the "Work hard to make their subjects interesting" indicator showed a quite moderate difference, with a score of 3.97 from the accounting undergraduate students and a score of 3.28 from the engineering undergraduate students.

The comparison of mean scores for the two remaining good teaching indicators, however, showed quite large differences, with scores from accounting and engineering undergraduate students of 3.89 and 2.83, and 3.82 and 2.60, respectively for "Motivate students to do their best work" and "Make a real effort to understand difficulties students might be having with their work" indicators.

Consequently, these findings can only provide some partial of support for P1. On one side, it is quite clear that both accounting and engineering undergraduate students consider the design of the course, the lecturers' comments on their work, and feedback from the lecturers on their progress, as the most important indicators of good teaching. Accounting undergraduate students also consider the lecturers' ability to explain as an important indicator of good teaching, while engineering undergraduate students also consider this indicator as important but to a slightly lesser extent.

On the other side, accounting undergraduate students consider the lecturers' efforts to make the subjects interesting as an important indicator of good teaching, but engineering undergraduate students consider this indicator only as moderately important. The noticeable differences obtained from this study are in the student perceptions on the lecturers' efforts to motivate students and the lecturers' efforts to understand the difficulties that are faced by the students. While accounting undergraduate students consider these two as important indicators 
of good teaching, engineering undergraduate students consider these two indicators as not too important. Apparently the engineering students do not regard lecturers' efforts to motivate students and to empathize with the students' situation as important to their learning since apparently they do not contribute to the transfer and communication of skills and knowledge. The characteristics of the disciplines may also contribute to these results, in which the engineering discipline is more technical and precise in nature while the accounting discipline, although sharing some levels of technical features and precision, is not as firm in those matters as the engineering discipline. Additionally, parts of the accounting discipline involve subjects and area which require discussion and analysis which are more qualitative in nature, and hence for accounting undergraduate students, motivational supports from the lecturers seemingly are more valuable and appreciated.

Table 3. Students' perceptions of good teaching by area of study

\begin{tabular}{|c|c|c|c|c|c|c|c|}
\hline & \multicolumn{7}{|c|}{ Good Teaching Indicators } \\
\hline & $\begin{array}{c}\text { Comment } \\
\text { on } \\
\text { students } \\
\text { work }\end{array}$ & $\begin{array}{c}\text { Give } \\
\text { helpful } \\
\text { feedback } \\
\text { on how } \\
\text { students } \\
\text { are going }\end{array}$ & $\begin{array}{c}\text { Motivate } \\
\text { students } \\
\text { to do } \\
\text { their best } \\
\text { work }\end{array}$ & $\begin{array}{c}\text { Explain } \\
\text { things } \\
\text { very } \\
\text { well }\end{array}$ & $\begin{array}{l}\text { Work hard } \\
\text { to make } \\
\text { their } \\
\text { subjects } \\
\text { interesting }\end{array}$ & $\begin{array}{c}\text { Make a real } \\
\text { effort to } \\
\text { understand } \\
\text { difficulties } \\
\text { students might } \\
\text { be having with } \\
\text { their work }\end{array}$ & $\begin{array}{c}\text { Design } \\
\text { the } \\
\text { course } \\
\text { very } \\
\text { well }\end{array}$ \\
\hline $\begin{array}{l}\text { Accounting } \\
(\mathrm{n}=323)\end{array}$ & & & & & & & \\
\hline Mean & 4.02 & 4.08 & 3.89 & 3.99 & 3.97 & 3.82 & 4.01 \\
\hline Std dev & 0.85 & 0.99 & 0.99 & 0.87 & 0.92 & 1.02 & 0.92 \\
\hline Minimum & 3 & 1 & 1 & 2 & 2 & 1 & 1 \\
\hline Maximum & 5 & 5 & 5 & 5 & 5 & 5 & 5 \\
\hline $\begin{array}{l}\text { Engineering } \\
(\mathrm{n}=205)\end{array}$ & & & & & & & \\
\hline Mean & 4.09 & 4.05 & 2.83 & 3.62 & 3.28 & 2.60 & 4.11 \\
\hline Std dev & 0.84 & 1.03 & 1.35 & 1.08 & 1.07 & 1.38 & 0.88 \\
\hline Minimum & 3 & 1 & 1 & 2 & 1 & 1 & 1 \\
\hline Maximum & 5 & 5 & 5 & 5 & 5 & 5 & 5 \\
\hline $\mathrm{T}$ & -0.921 & 0.319 & 9.719 & 4.083 & 7.598 & 10.867 & -1.239 \\
\hline Sig & 0.357 & 0.750 & $0.000^{*}$ & $0.000 *$ & $0.000^{*}$ & $0.000 *$ & 0.216 \\
\hline
\end{tabular}

Notes: * Significant at $p<0.01$ 
4.3 Students' perceptions of good teaching by gender

The means of the scores on good teaching scales of female undergraduate students as compared to their male counterparts' scores are shown in Table 4. The initial indications from the descriptive statistics showed that the scores made by female undergraduate students in all good teaching scales were similar to those of their male counterparts, except for the "Give helpful feedback on how students are going" indicator. The resultsi of the comparison of the mean scores confirmed that "Give helpful feedback on how students are going" was the only indicator that was significantly different between female and male undergraduate students, in which the level of importance of this indicator perceived by male undergraduate students was comparatively higher to that perceived by their female counterparts. It was difficult to make a presumption on what factors affect this difference. Hofstede's (2001) suggestions regarding the differences between masculine and feminine traits may provide some rationalization about this. It is said that men are supposed to be assertive and tough, and women are supposed to be more modest and tender. Hence, as a consequence there may be a tendency that male undergraduate students, comparatively to their female counterparts, expect more feedback provided by their lecturers.

In general, we could make a conclusion that there were no significant differences between overall good teaching scores of the female and male undergraduate students. These findings provide a reasonable level of support for $\mathrm{P} 2$, and hence can provide some evidence that female and male undergraduate students have similar perceptions regarding the importance of indicators of good teaching. 


\section{Macrothink}

Table 4. Students' perceptions of good teaching by gender

\begin{tabular}{|c|c|c|c|c|c|c|c|}
\hline & \multicolumn{7}{|c|}{ Good Teaching Indicators } \\
\hline & $\begin{array}{l}\text { Comment } \\
\text { on } \\
\text { students' } \\
\text { work }\end{array}$ & $\begin{array}{c}\text { Give } \\
\text { helpful } \\
\text { feedback } \\
\text { on how } \\
\text { students } \\
\text { are going }\end{array}$ & $\begin{array}{l}\text { Motivate } \\
\text { students } \\
\text { to do their } \\
\text { best work }\end{array}$ & $\begin{array}{c}\text { Explain } \\
\text { things } \\
\text { very } \\
\text { well }\end{array}$ & $\begin{array}{l}\text { Work hard } \\
\text { to make } \\
\text { their } \\
\text { subjects } \\
\text { interesting }\end{array}$ & $\begin{array}{c}\text { Make a real } \\
\text { effort to } \\
\text { understand } \\
\text { difficulties } \\
\text { students might } \\
\text { be having with } \\
\text { their work }\end{array}$ & $\begin{array}{c}\text { Design } \\
\text { the } \\
\text { course } \\
\text { very } \\
\text { well }\end{array}$ \\
\hline \multicolumn{8}{|l|}{$\begin{array}{l}\text { Females } \\
(\mathrm{n}=280)\end{array}$} \\
\hline Mean & 4.10 & 3.88 & 3.53 & 3.81 & 3.65 & 3.28 & 4.00 \\
\hline Std dev & 0.85 & 1.08 & 1.23 & 1.00 & 0.99 & 1.33 & 0.96 \\
\hline Minimum & 3 & 1 & 1 & 2 & 1 & 1 & 1 \\
\hline Maximum & 5 & 5 & 5 & 5 & 5 & 5 & 5 \\
\hline \multicolumn{8}{|l|}{$\begin{array}{l}\text { Males } \\
(\mathrm{n}=248)\end{array}$} \\
\hline Mean & 4.00 & 4.23 & 3.44 & 3.88 & 3.74 & 3.40 & 4.09 \\
\hline Std dev & 0.83 & 0.90 & 1.27 & 0.95 & 1.07 & 1.29 & 0.85 \\
\hline Minimum & 3 & 1 & 1 & 2 & 1 & 1 & 2 \\
\hline Maximum & 5 & 5 & 5 & 5 & 5 & 5 & 5 \\
\hline $\mathrm{t}$ & 1.320 & -3.953 & 0.851 & -0.754 & -1.037 & -1.063 & -1.128 \\
\hline Sig & 0.187 & $0.000^{*}$ & 0.395 & 0.451 & 0.300 & 0.288 & 0.260 \\
\hline
\end{tabular}

Notes: * Significant at $p<0.01$

\subsection{Students' perceptions of good teaching by year of study}

The means of the scores on good teaching scales of undergraduate students based on their year of study are shown in Tables 5a to 5c.

The initial indications from the descriptive statistics showed that the scores made by first year undergraduate students in all good teaching scales were similar to those of second year undergraduate students, except for the "Motivate students to do their best work" indicator. The results of the comparison of the mean scores confirmed that "Motivate students to do their best work" was the only indicator that was significantly different between first year and second year undergraduate students, in which the level of importance of this indicator perceived by the first year undergraduate students was comparatively higher to that perceived by the second year undergraduate students (see Table 5a).

The descriptive statistics and the comparison of the mean scores for second year and third year undergraduate students showed that there were no significant differences between good 


\section{Macrothink}

teaching scores of the second year and third year undergraduate students (see table 5b). However, the analysis and comparisons of the scores made by first year and third year undergraduate students showed similar results to those of first year and second year undergraduate students, in which "Motivate students to do their best work" was the only indicator that was significantly different between first year and third year undergraduate students. The level of importance of this indicator perceived by the first year undergraduate students was comparatively higher to that perceived by the third year undergraduate students (see Table 5c).

A possible explanation of this difference was that first year undergraduate students were relatively younger students who most had just completed their high schools and might face some challenges in dealing with a new environment and a new university culture. Hence, consequently they may need more assurance and encouragement from their lecturers. The results indicated that this "Motivate students to do their best work" indicator would be perceived as less important once the students reach the second or third year level in their study.

In general, we could make a conclusion that there were no significant differences between overall good teaching scores of the first year, second year and third year undergraduate students. These findings provide a reasonable level of support for P3, and hence can provide some evidence that undergraduate students have similar perceptions regarding the importance of indicators of good teaching irrespective of their year of study. 


\section{Macrothink}

Asian Journal of Finance \& Accounting ISSN 1946-052X 2012, Vol. 4, No. 2

Table 5a. Students' perceptions of good teaching by year of study (comparisons between first and second year students)

\begin{tabular}{|c|c|c|c|c|c|c|c|}
\hline & \multicolumn{7}{|c|}{ Good Teaching Indicators } \\
\hline & $\begin{array}{c}\text { Comment } \\
\text { on } \\
\text { students' } \\
\text { work }\end{array}$ & $\begin{array}{c}\text { Give } \\
\text { helpful } \\
\text { feedback } \\
\text { on how } \\
\text { students } \\
\text { are going }\end{array}$ & $\begin{array}{l}\text { Motivate } \\
\text { students } \\
\text { to do their } \\
\text { best work }\end{array}$ & $\begin{array}{c}\text { Explain } \\
\text { things } \\
\text { very } \\
\text { well }\end{array}$ & $\begin{array}{l}\text { Work hard } \\
\text { to make } \\
\text { their } \\
\text { subjects } \\
\text { interesting }\end{array}$ & $\begin{array}{c}\text { Make a real } \\
\text { effort to } \\
\text { understand } \\
\text { difficulties } \\
\text { students might } \\
\text { be having with } \\
\text { their work }\end{array}$ & $\begin{array}{c}\text { Design } \\
\text { the } \\
\text { course } \\
\text { very } \\
\text { well }\end{array}$ \\
\hline $\begin{array}{l}\text { First year } \\
(n=247)\end{array}$ & & & & & & & \\
\hline Mean & 4.05 & 4.10 & 3.71 & 3.85 & 3.74 & 3.39 & 4.05 \\
\hline Std dev & 0.84 & 0.98 & 1.15 & 0.97 & 0.98 & 1.29 & 0.92 \\
\hline Minimum & 3 & 1 & 1 & 2 & 2 & 1 & 1 \\
\hline Maximum & 5 & 5 & 5 & 5 & 5 & 5 & 5 \\
\hline $\begin{array}{l}\text { Second } \\
\text { year } \\
(n=166)\end{array}$ & & & & & & & \\
\hline Mean & 4.11 & 4.06 & 3.37 & 3.87 & 3.61 & 3.37 & 4.05 \\
\hline Std dev & 0.81 & 1.00 & 1.26 & 0.98 & 1.09 & 1.31 & 0.83 \\
\hline Minimum & 3 & 1 & 1 & 2 & 1 & 1 & 2 \\
\hline Maximum & 5 & 5 & 5 & 5 & 5 & 5 & 5 \\
\hline t & -0.721 & 0.415 & 2.821 & -0.136 & 1.297 & 0.147 & -0.063 \\
\hline $\operatorname{sig}$ & 0.472 & 0.678 & $0.005^{*}$ & 0.892 & 0.196 & 0.883 & 0.950 \\
\hline
\end{tabular}

Notes: * Significant at $p<0.01$ 


\section{Macrothink}

Asian Journal of Finance \& Accounting ISSN 1946-052X 2012, Vol. 4, No. 2

Table 5b. Students' perceptions of good teaching by year of study (comparisons between second and third year students)

\begin{tabular}{|c|c|c|c|c|c|c|c|}
\hline & \multicolumn{7}{|c|}{ Good Teaching Indicators } \\
\hline & $\begin{array}{c}\text { Comment } \\
\text { on } \\
\text { students' } \\
\text { work }\end{array}$ & $\begin{array}{c}\text { Give } \\
\text { helpful } \\
\text { feedback } \\
\text { on how } \\
\text { students } \\
\text { are going }\end{array}$ & $\begin{array}{c}\text { Motivate } \\
\text { students to } \\
\text { do their } \\
\text { best work }\end{array}$ & $\begin{array}{c}\text { Explain } \\
\text { things } \\
\text { very well }\end{array}$ & $\begin{array}{c}\text { Work } \\
\text { hard to } \\
\text { make their } \\
\text { subjects } \\
\text { interesting }\end{array}$ & $\begin{array}{c}\text { Make a } \\
\text { real effort } \\
\text { to } \\
\text { understand } \\
\text { difficulties } \\
\text { students } \\
\text { might be } \\
\text { having } \\
\text { with their } \\
\text { work }\end{array}$ & $\begin{array}{l}\text { Design the } \\
\text { course } \\
\text { very well }\end{array}$ \\
\hline $\begin{array}{l}\text { Second } \\
\text { year } \\
(n=166)\end{array}$ & & & & & & & \\
\hline Mean & 4.11 & 4.06 & 3.37 & 3.87 & 3.61 & 3.37 & 4.05 \\
\hline Std dev & 0.81 & 1.00 & 1.26 & 0.98 & 1.09 & 1.31 & 0.83 \\
\hline Minimum & 3 & 1 & 1 & 2 & 1 & 1 & 2 \\
\hline Maximum & 5 & 5 & 5 & 5 & 5 & 5 & 5 \\
\hline $\begin{array}{l}\text { Third } \\
\text { year } \\
(n=115)\end{array}$ & & & & & & & \\
\hline Mean & 3.95 & 4.00 & 3.15 & 3.81 & 3.73 & 3.21 & 4.05 \\
\hline Std dev & 0.89 & 1.08 & 1.35 & 0.99 & 1.07 & 1.34 & 0.96 \\
\hline Minimum & 3 & 1 & 1 & 2 & 2 & 1 & 1 \\
\hline Maximum & 5 & 5 & 5 & 5 & 5 & 5 & 5 \\
\hline $\mathrm{t}$ & 1.546 & 0.481 & 1.431 & 0.493 & -0.927 & 1.025 & 0.018 \\
\hline sig & 0.123 & 0.631 & 0.154 & 0.622 & 0.355 & 0.306 & 0.985 \\
\hline
\end{tabular}

Notes: * Significant at $p<0.01$ 


\section{Macrothink}

Asian Journal of Finance \& Accounting ISSN 1946-052X 2012, Vol. 4, No. 2

Table 5c. Students' perceptions of good teaching by year of study (comparisons between first and third year students)

\begin{tabular}{|c|c|c|c|c|c|c|c|}
\hline & \multicolumn{7}{|c|}{ Good Teaching Indicators } \\
\hline & $\begin{array}{c}\text { Comment } \\
\text { on } \\
\text { students' } \\
\text { work }\end{array}$ & $\begin{array}{c}\text { Give } \\
\text { helpful } \\
\text { feedback } \\
\text { on how } \\
\text { students } \\
\text { are going }\end{array}$ & $\begin{array}{c}\text { Motivate } \\
\text { students to } \\
\text { do their } \\
\text { best work }\end{array}$ & $\begin{array}{c}\text { Explain } \\
\text { things } \\
\text { very well }\end{array}$ & $\begin{array}{c}\text { Work } \\
\text { hard to } \\
\text { make their } \\
\text { subjects } \\
\text { interesting }\end{array}$ & $\begin{array}{c}\text { Make a } \\
\text { real effort } \\
\text { to } \\
\text { understand } \\
\text { difficulties } \\
\text { students } \\
\text { might be } \\
\text { having } \\
\text { with their } \\
\text { work }\end{array}$ & $\begin{array}{l}\text { Design the } \\
\text { course } \\
\text { very well }\end{array}$ \\
\hline $\begin{array}{l}\text { First year } \\
(\mathrm{n}=247)\end{array}$ & & & & & & & \\
\hline Mean & 4.05 & 4.10 & 3.71 & 3.85 & 3.74 & 3.39 & 4.05 \\
\hline Std dev & 0.84 & 0.98 & 1.15 & 0.97 & 0.98 & 1.29 & 0.92 \\
\hline Minimum & 3 & 1 & 1 & 2 & 2 & 1 & 1 \\
\hline Maximum & 5 & 5 & 5 & 5 & 5 & 5 & 5 \\
\hline $\begin{array}{l}\text { Third } \\
\text { year } \\
(\mathrm{n}=115)\end{array}$ & & & & & & & \\
\hline Mean & 3.95 & 4.00 & 3.15 & 3.81 & 3.73 & 3.21 & 4.05 \\
\hline Std dev & 0.89 & 1.08 & 1.35 & 0.99 & 1.07 & 1.34 & 0.96 \\
\hline Minimum & 3 & 1 & 1 & 2 & 2 & 1 & 1 \\
\hline Maximum & 5 & 5 & 5 & 5 & 5 & 5 & 5 \\
\hline $\mathrm{t}$ & 1.044 & 0.886 & 3.871 & 0.414 & 0.123 & 1.246 & -0.034 \\
\hline sig & 0.297 & 0.376 & $0.000 *$ & 0.679 & 0.902 & 0.213 & 0.973 \\
\hline
\end{tabular}

Notes: * Significant at $p<0.01$ 


\section{Conclusions}

The overall results of this study suggest that in general undergraduate students perceived all seven of the good teaching indicators as important. Both accounting and engineering undergraduate students are in agreement that the design of the course, the lecturers' comments on their work, and feedback from the lecturers on their progress are the most important indicators of good teaching. Both accounting and engineering undergraduate students also feel that the lecturers' ability to explain is an important indicator of good teaching, but its importance is emphasized to a slightly bigger extent by the accounting undergraduate students. The obvious differences are in the student perceptions on the lecturers' efforts to make the subjects interesting, to motivate students and to understand the difficulties that are faced by the students. Accounting undergraduate students consider these three attributes as important, but not so in the eyes of the engineering undergraduate students. Finally, overall, undergraduate students have similar perceptions regarding the importance of indicators of good teaching irrespective of their gender or year of study.

The results of this study have some implications for accounting and engineering lecturers wishing to improve the quality of teaching and learning for their students. First, it should be noted that as much as we know that what students want does not always capture the opportunity for the lecturers to foster the creation of learning and does not always correspond with the unique characteristics of certain subjects, there are always good lessons that can be learned and applied from the students' perspectives. Second, this study provides some evidence that the good teaching scales used in this study are overall considered important by the students, and hence provides some level of assurance that the implementation of these indicators for student evaluation could offer mutual benefits to both the lecturers and the students.

\section{References}

Botas, P.C.P. (2008). Students' perceptions of quality teaching in the UK: The MA in education case. Higher Education Review, 40(3), 50-68.

Blackmore, J. (2009). Academic pedagogies, quality logics and performative universities: evaluating teaching and what students want. Studies in Higher Education, 34(8), 857-872. http://dx.doi.org/10.1080/03075070902898664

Crumbley, L., Henry, B.K. \& Kratchman, S.H. (2001). Students' perceptions of the evaluation of college teaching. Quality Assurance in Education, 9(4), 197-207. http://dx.doi.org/10.1108/EUM0000000006158

Emery, C.R., Kramer, T.R., and Tian, R.G. (2003). Return to academic standards: a critique of student evaluations of teaching effectiveness. Quality Assurance in Education, 11(1), 37-46. http://dx.doi.org/10.1108/09684880310462074

Feldman, K.A. (1976). The superior college teacher from the students' view. Research in Higher Education, 5, 243-288. http://dx.doi.org/10.1007/BF00991967 


\section{$\triangle$ Macrothink}

Fuhrman, N.E., Fuhrman, R.G. \& DeLay, A.M. (2010). Defining "good teaching” at the graduate level: are we meeting the instructional expectations of doctoral students? Journal of Faculty Development, 24(2), 19-24.

Goodwin, L.D. \& Stevens, E.A. (1993). The influence of gender on university faculty members' perceptions of "good" teaching. Journal of Higher Education, 64(2), 166-185. http://dx.doi.org/10.2307/2960028

Graduate Careers Australia (2011). Graduate Course Experience 2010. Melbourne: Graduate Careers Australia Ltd.

Hativa, N. (1984). Good teaching of mathematics as perceived by undergraduate students. International Journal of Mathematical Education in Science and Technology, 15(5), 605-615. http://dx.doi.org/10.1080/0020739840150508

Holmes, K. \& Papageorgiou, G. (2009). Good, bad and insufficient: students' expectations, perceptions and uses of feedback. Journal of Hospitality, Leisure, Sport \& Tourism Education, 8(1), 85-96. http://dx.doi.org/10.3794/johlste.81.183

Hofstede, G. (2001). Culture's consequences: Comparing values, behaviors, institutions, and organizations across nations. Thousand Oaks, California: Sage Publications, Inc.

Kember, D., Jenkins, W., \& Ng, K.C. (2003). Adult students' perceptions of good teaching as a function of their conceptions of learning - part 1. Influencing the development of self-determination. Studies in Continuing Education, 25(2), 239-251. http://dx.doi.org/10.1080/0158037032000131556

Kember, D., Jenkins, W. \& Ng, K.C. (2004). Adult students' perceptions of good teaching as a function of their conceptions of learning - part 2. Implications for the evaluation of teaching. Studies in Continuing Education, 26(1), 81-97. http://dx.doi.org/10.1080/158037042000199461

Mitsis, A. \& Foley, P. (2009). Culturally-anchored values and university education experience perception. International Journal of Educational Management, 23(6), 484-504. http://dx.doi.org/10.1108/09513540910981023

Surrat, C.K. \& Desselle, S.P. (2007). Pharmacy students' perceptions of a teaching evaluation process. American Journal of Pharmaceutical Education, 71(1), 1-7. http://dx.doi.org/10.5688/aj710106

Tootoonchi, A., Lyons, P., \& Hagen, A. (2002). MBA students' perceptions of effective teaching methodologies and instructor characteristics. International Journal of Commerce and Management, 12(1), 79-93. http://dx.doi.org/10.1108/eb047438

Vieira, F. (2002). Pedagogic quality at universities: what teachers and students think. Quality in Higher Education, 8(3), 255-272. http://dx.doi.org/10.1080/1353832022000031647

Xiao, Z. \& Dyson, J.R. (1999). Chinese students' perceptions of good accounting teaching. Accounting Education, 8(4), 341-361. http://dx.doi.org/10.1080/096392899330838 